\title{
Does the Decrease in Neutrophil-lymphocyte Ratio after BCG Treatment Be a Prognostic Marker for NMIBC?
}

\author{
BCG Tedavisi ile Nötrofil-lenfosit Oranındaki Azalma NMIBC için Prognostik Bir Belirteç \\ Olabilir Mi?
}

\author{
(D) Aykut Başer \\ Hitit University Faculty of Medicine, Department of Urology, Çorum, Turkiye
}

\section{What's known on the subject? and What does the study add?}

The neutrophil-lymphocyte ratio (NLR) has prognostic value for bladder cancer. However, a unique finding of our study is that the decrease in NLR with Bacillus Calmette-Guerin treatment is a good indicator of improved prognosis.

\section{Abstract}

Objective: Non-muscle invasive bladder cancer (NMIBC) accounts for 75\% of all bladder cancer cases. Several models to predict relapses and progression have been developed. We aimed to determine the predictive value of the neutrophil-lymphocyte ratio (NLR) for recurrence and/or progression of the disease.

Materials and Methods: Seventy patients with high-risk NMIBC according to the European Organization for Research and Treatment of Cancer (EORTC) risk classification who were receiving Bacillus Calmette-Guerin (BCG) treatment and were followed up at our clinic were included in the study.

Results: The average score level and NLR values differed significantly on patient classification according to the EORTC Progression and Recurrence Risk score. The positive correlations among EORTC Recurrence score, EORTC Progression score, Club Urológico Espanol de Tratamiento Oncológico (CUETO) Recurrence score, and CUETO Progression score and NLR values were not statistically significant. The NLR values decreased significantly on follow-ups on BCG treatment.

Conclusion: Patients with bladder cancer have a high NLR, which has predictive utility with regard to prognosis. A decrease in NLR with BCG treatment is indicative of the decreased likelihood of recurrence and progression.

Keywords: Non-muscle invasive bladder cancer, Neutrophil-lymphocyte ratio, BCG treatment, EORTC risk classification, Progression, Recurrence

Öz

Amaç: Kas invazif olmayan mesane kanserleri, tüm mesane kanserlerinin \%75'ini oluşturmaktadır. Relaps and progresyonu tahmin etmek için bir çok model geliş̧irilmiştir. European Organization for Research and Treatment of Cancer (EORTC) risk sınıflandırmasına göre yüksek risk kategorisinde olup Bacillus Calmette-Guerin (BCG) tedavisi başlanmış ve 1 yıllık BCG tedavisinde nüks ve progresyon gözlenmemiş hastalar retrospektif olarak analiz edildi. Bu durumu tahmin edebilecek nötrofil/lenfosit oranları (NLR) araştırıldı.

Gereç ve Yöntem: EORTC risk sınıflandırmasına göre yüksek risk grubunda BCG tedavisi başlatılan ve kliniğimizde takip edilen 70 hasta çalışmaya dahil edildi.

Bulgular: EORTC Progresyon ve Rekürrens Risk Skoru Sınıflamasına göre skor seviyesi ve NLR değerlerinin ortalaması istatistiksel olarak farklı bulundu. EORTC Rekürrens skoru, EORTC İlerleme skoru, Club Urológico Espanol de Tratamiento Oncológico (CUETO) Rekürrens skoru ve CUETO Progresyon skoru artışı ve NLR değerleri arasında yapılan korelasyon analizinde istatistiksel olarak anlamlı bir sonuç saptanmadı. BCG tedavisi ile birlikte takiplerde NLR değerleri önemli ölçüde azaldı.

Sonuç: NLR değeri mesane kanseri ile ilişkili olarak artmakta ve progresyon ve rekürrens tahmini için bir prognoz parametresi olarak kullanılabilir. BCG tedavisi ile birlikte değerinde düşme olması rekürrens ve progresyon olmamasının bir göstergesi olabilir.

Anahtar Kelimeler: Kas invazif olmayan mesane kanseri, Nötrofil-lenfosit oranı, BCG tedavisi, EORTC risk sınıflması, Progresyon, Nüks

Correspondence: Aykut Başer MD, Hitit University Faculty of Medicine, Department of Urology, Corum, Turkiye Phone: +90 5055606932 E-mail: aqut85@windowslive.com ORCID-ID: orcid.org/0000-0003-0457-512X

Received: 27.01.2020 Accepted: 14.04.2020

Cite this article as: Aykut Başer. Does the Decrease in Neutrophil-lymphocyte Ratio with BCG Treatment Be a Prognostic Marker for NMIBC? J Urol Surg 2020;7(4):271-275.

๑Copyright 2020 by the Association of Urological Surgery / Journal of Urological Surgery published by Galenos Publishing House. 


\section{Introduction}

Bladder cancer $(\mathrm{BC})$ is the $9^{\text {th }}$ or $11^{\text {th }}$ most common cancer globally, including in both the sexes $(1,2)$. Among men, it is the $4^{\text {th }}-7^{\text {th }}$ most common cancer (1-4). The global incidence rate of BC standardized by age is 9.0 and 2.2 per 100,000 males and females per year, respectively (1). BC is the most common among genitourinary system tumors.

Approximately $75 \%$ of the patients receive the diagnosis of non-muscle invasive, submucosa (stage T1) or mucosal [stage Ta or carcinoma in situ (CIS)] neoplasia $(1,5-7)$. Because non-muscle invasive bladder cancer (NMIBC) constitutes a heterogeneous group, its recurrence and progression also differ by stages and grades. The European Organization for Research and Treatment of Cancer (EORTC) and Club Urológico Espanol de Tratamiento Oncológico (CUETO) risk tables were devised to predict recurrence and progression. Furthermore, NMIBCs have been divided into low-, medium-, and high-risk groups for the EORTC treatment protocol. The European Urology Guide (EAU) guidelines recommend the treatment protocol according to these risk groups. However, reliable prognostic factors that can help in patient-specific estimation rather than group-specific estimation of recurrence and progression risk are lacking (8). Tumor-induced host inflammatory responses play an important role in tumor development and progression. According to the literature, hematologic markers have been used in predicting prognosis in various cancers and urothelial carcinoma. The neutrophil-to-lymphocyte ratio (NLR) has been used as a marker in various types of cancer, and it has been shown to be of predictive value for prognosis $(9,10)$. In patients with NMIBC, increase in NLR has been shown to be associated with progression and recurrence (11). NLR is a hematologic parameter that can be determined easily and quickly. The inclusion of NLR along with parameters such as number of tumors, tumor size, tumor stage, tumor grade, presence of concomitant CIS, and previous recurrence in progression and recurrence prediction models could be useful. Consensus on a threshold NLR value is lacking (12).

We aimed to investigate the predictive value of changes in NLR with regard to progression and recurrence after 1 year maintenance BCG treatment in patients with high-risk NMIBC and to determine the association between NLR and EORTC progression and recurrence risk classifications.

\section{Materials and Methods}

This study complied with the Helsinki Declaration and was conducted with the approval of the local ethics committee (Hitit University Faculty of Medicine Ethics Committee; decision no: 87). Patients undergoing transurethral bladder tumor resection
(TURB) due to bladder tumor between September 2015 and September 2018 at a single center were retrospectively screened. The pathology reports followed the 2009 TNM classification and 2004 WHO grading system. We included 70 patients classified as high-risk according to the EORTC risk classification (2019 EAU NMIBC guideline recommendations; T1, grade 3, presence of $\mathrm{CIS}$, multiple, recurrent, or tumor diameter $>3 \mathrm{~cm}$ ) who were receiving BCG treatment and were being followed up at our clinic.

The medical records, laboratory results, and pathology reports of the patients included in the study were evaluated. The number of tumors, tumor size, and previous recurrence rate before TURB, and tumor stage, tumor grade, and the presence of accompanying CIS in line with the pathology report after TURB were obtained from the medical records. Recurrence and progression scores were calculated according to the EORTC risk tables. Similarly, CUETO recurrence and progression scores were calculated.

Neutrophil and lymphocyte counts of the patients were calculated by dividing the absolute neutrophil values by the absolute lymphocyte values at different time points: NLR 1 , pre-TURB; NLR 2, before control cystoscopy performed after 6 courses of BCG treatment; NLR 3, hemogram values before control cystoscopy performed after 1 year of BCG induction.

We excluded patients with non-transitional $B C$, transitional cell $\mathrm{BC}$ without muscle invasion, cancer other than $\mathrm{BC}$, hematological and bleeding disorders, BCG intolerance, and BCG failures.

\section{Statistical Analysis}

IBM SPSS for Windows, version 22.0, was used for statistical analyses. Means, standard deviations, and percentages were calculated for descriptive statistics. The Student t-test and 1-way analysis of variance (ANOVA) were used for parametric data, and the Mann-Whitney $U$ and Kruskal-Wallis tests were used for non-parametric data. Repeated-measures ANOVA and Freidman tests were used for the analysis of repeating measurements, and the chi-square or Fischer Exact test was used to evaluate categorical data. The results were expressed at a 95\% confidence interval, and $p<0.05$ was considered statistically significant.

\section{Results}

From among the patients in the EORTC high-risk group undergoing BCG treatment between January 2015 and September 2018, 70 patients who did not have recurrence and progression in the first year of maintenance treatment were included in the study. The associations between the clinical features of EORTC and CUETO scoring in the high-risk group and NLR were examined. 
The mean age of the study population (59 males and 11 females) was $68.06 \pm 9.70$ years. The values of tumor-related features, EORTC and CUETO recurrence and progression scores, and NLRs of the patients at 1-year follow-up are summarized in Table 1.

Table 1. Tumor-related characteristics of patients, EORTC and CUETO recurrence and progression scores, and 1-year follow-up values of NLR

\begin{tabular}{|c|c|c|c|}
\hline & & $n$ & $\%$ \\
\hline \multicolumn{2}{|l|}{ Age (years) } & $68.06 \pm 9.70$ & \\
\hline \multicolumn{2}{|l|}{ Male } & 59 & 84.3 \\
\hline \multicolumn{2}{|l|}{ Female } & 11 & 15.7 \\
\hline \multirow[t]{3}{*}{ Number of tumors } & Single & 38 & 54.3 \\
\hline & $2-7$ & 24 & 34.3 \\
\hline & $\geq 8$ & 8 & 11.4 \\
\hline \multirow[t]{2}{*}{ Tumor diameter } & $<3 \mathrm{~cm}$ & 27 & 38.6 \\
\hline & $\geq 3 \mathrm{~cm}$ & 43 & 61.4 \\
\hline \multirow[t]{2}{*}{ Category } & $\mathrm{Ta}$ & 12 & 17.1 \\
\hline & $\mathrm{T} 1$ & 58 & 82.9 \\
\hline \multirow[t]{2}{*}{ Concurrent CIS } & Yes & 7 & 10 \\
\hline & No & 63 & 90 \\
\hline \multirow[t]{2}{*}{ Grade } & $\mathrm{G} 1$ & 12 & 17.1 \\
\hline & G3 & 58 & 82.9 \\
\hline \multirow[t]{3}{*}{ Prior recurrence rate } & Primer & 56 & 80 \\
\hline & $\leq 1 /$ year & 14 & 20 \\
\hline & $>1 /$ year & 0 & 0 \\
\hline \multicolumn{2}{|l|}{ EORTC Recurrence score } & $6.43 \pm 3.36$ & \\
\hline \multirow{3}{*}{$\begin{array}{l}\text { EORTC Recurrence score } \\
\text { classification }\end{array}$} & $1-4$ & 25 & 35.7 \\
\hline & $5-9$ & 32 & 45.7 \\
\hline & $10-17$ & 13 & 18.6 \\
\hline \multicolumn{2}{|l|}{ EORTC Progression score } & $11.57 \pm 3.95$ & \\
\hline \multirow{3}{*}{$\begin{array}{l}\text { EORTC Progression score } \\
\text { classification }\end{array}$} & $2-6$ & 7 & 10 \\
\hline & $7-13$ & 37 & 52.9 \\
\hline & $14-23$ & 26 & 37.1 \\
\hline \multicolumn{2}{|l|}{ CUETO Recurrence score } & $5.50 \pm 3.17$ & \\
\hline \multicolumn{2}{|l|}{ CUETO Progression score } & $7.97 \pm 3.19$ & \\
\hline \multicolumn{2}{|l|}{ NLR 1} & $2.31 \pm 1.03$ & \\
\hline \multicolumn{2}{|l|}{ NLR 2} & $2.24 \pm 1.17$ & \\
\hline \multicolumn{2}{|l|}{ NLR 3} & $2.13 \pm 1.10$ & \\
\hline \multicolumn{2}{|l|}{ Total } & 70 & 100.0 \\
\hline \multicolumn{4}{|c|}{$\begin{array}{l}\text { EORTC: European organization for research and treatment of cancer, CUETO: Club } \\
\text { Urológico Espanol de Tratamiento Oncológico, NLR: Neutrophil-lymphocyte ratio, CIS: } \\
\text { Carcinoma in situ }\end{array}$} \\
\hline
\end{tabular}

We investigated the threshold values of NLR1 measurement according to the EORTC Progression and Recurrence Risk score classification in predicting non-progression and nonrecurrence in high-risk NMIBCs at the first 1-year maintenance BCG treatment. Upon dividing the patients into 3 groups according to the EORTC Recurrence score and Progression score classifications, the mean NLR1 values differed significantly only in the high-score group per the EORTC recurrence score classification ( $p=0.023$; Table 2).

According to repeated-measures ANOVA, NLR1 differed significantly from NLR2 and NLR3 on induction BCG treatment ( $p=0.002$; Table 3 ).

Among patients with high-risk NMIBC, the threshold NLR1 values for non-recurrence after 1 year of BCG treatment were 1.88 with a score of $1-4,2.47$ for a score of 5-9, and 2.75 for a score of 10-17, according to the EORTC Recurrence score classification.

\section{Discussion}

The prediction of recurrence and progression is critical in cases of NMIBC. Patients with NMIBC are divided into risk groups according to prognostic factors, which allows for appropriate treatment to be administered. The EORTC risk table lists probabilities of recurrence and importantly, risk of progression. The risk scoring model was created by CUETO for patients treated with BCG. Although the EORTC and CUETO risk classifications are currently used to predict recurrence and progression, effort to find novel parameters has been ongoing. NLR is an indicator of systemic inflammation. Neutrophils and lymphocytes have immunomodulatory activities. Several studies investigating the prognostic role of NLR in many solid tumors have yielded significant results. Paramanathan et al. (13) found that high NLR values in solid tumors were associated with poorer overall survival rates and cancer-specific survival rates and noted that NLR was preferred for its easy availability and easy evaluation.

Studies have reported a positive correlation between the NLR and recurrence and progression in patients with NMIBC

Table 3. Change in NLR value after 1-year BCG treatment

\begin{tabular}{|l|l|l|l|l|}
\hline & NLR1 & NLR2 & NLR3 & p \\
\hline $\begin{array}{l}\text { Neutrophil- } \\
\text { lymphocyte ratio }\end{array}$ & $2.31 \pm 1.03$ & $2.24 \pm 1.17$ & $2.13 \pm 1.10$ & 0.002 \\
\hline \multicolumn{4}{|l}{ NLR: Neutrophil-lymphocyte ratio, BCG: Bacillus Calmette-Guerin } \\
\hline
\end{tabular}

Table 2. NLR1 value according to EORTC progression and recurrence risk score classification

\begin{tabular}{|c|c|c|c|c|c|c|c|c|}
\hline & \multicolumn{3}{|c|}{ EORTC Recurrence score classification } & \multirow[t]{2}{*}{$\mathbf{p}$} & \multicolumn{3}{|c|}{ EORTC Progression score classification } & \multirow[t]{2}{*}{$\mathbf{p}$} \\
\hline & $1-4$ & $5-9$ & $10-14$ & & $2-6$ & $7-13$ & $14-23$ & \\
\hline NLR1 & $1.88 \pm 0.54$ & $2.47 \pm 1.05$ & $2.75 \pm 1.43$ & 0.023 & $1.78 \pm 0.64$ & $2.18 \pm 0.85$ & $2.63 \pm 1.26$ & 0.087 \\
\hline
\end{tabular}


(11,14-19). Furthermore, association between NLR and tumor aggressiveness has also been reported (14,20-22). The threshold values for prediction of non-progression and nonrecurrence vary in the literature. In the study by Mano et al. (14) that included 122 patients with newly diagnosed NMIBC, the threshold NLR value was 2.41 ; they reported that T1 tumor incidence was higher and 3-year progression-free survival was lower in the NLR $>2.41$ group, which was associated with the EORTC high-risk group. Racioppi et al. (15) in their study of 100 patients considered the NLR threshold as 3; they reported that the incidence of $\mathrm{ClS}$, tumors of diameter $>3 \mathrm{~cm}$, and multiple tumors was significantly higher in the NLR $>3$ patient group. Yuk et al. (16) included 385 patients with NMIBC who received BCG treatment; they reported that NLR $\geq 1.5$ was associated with poor prognosis, with regard to overall survival and cancerspecific survival. Favilla et al. (17) conducted a prospective study including 178 patients to evaluate the role of NLR as a biomarker of NMIBC; they found that a higher NLR (NLR threshold $\geq 3$ ) predicted disease recurrence in patients with NMIBC but did not predict disease progression. In their retrospective study, D'Andrea et al. (18) included 918 patients under BCG treatment and considered an NLR threshold of 3; they reported that $N L R \geq 3$ was significantly associated with recurrence-free and progression-free survival. Çelen et al. (19) reported high recurrence rates with NLR $>2.5$. Aydın et al. (20) reported that $\mathrm{NLR}>2.41$ was associated with higher incidence of T1 tumor, G3 tumor, tumor diameter $>3 \mathrm{~cm}$, and multiple tumors and that the high-risk group (according to EORTC risk classification) had higher NLR values. Varying NLR thresholds have been considered in various studies, and a consensus in this regard is lacking. Most studies grouped patients on the basis of occurrence or nonoccurrence of recurrence and progression. Although an agreedupon NLR threshold, such as the international normalized ratio is required, recurrence and progression of BC are affected by several factors, which make arriving at a common NLR value challenging. An increase in NLR is reportedly associated with tumor aggressiveness and prognosis. We did not compare patients with and without recurrence and progression; hence, we could not suggest a threshold NLR. However, our study evaluated recurrence and progression after 1-year of BCG treatment. Racioppi et al. (15) reported a linear relationship between the NLR value and EORTC Recurrence Risk score and EORTC Progression score. Similarly, Aydın et al. (20) observed that recurrence and progression scores increased significantly as the NLR value increased. Consistent with the published findings, NLR values increased as the EORTC Recurrence and Progression scores increased in our study, with the correlation achieving statistical significance only with the EORTC Recurrence score. We recommend using the following NLR1 values to predict nonrecurrence after 1 year of BCG treatment among patients with high-risk NMIBC: 1.88 for those with a score of 1-4, 2.47 for those with a score of 5-9, and 2.75 for those with a score of 10-17, according to the EORTC recurrence score classification. Aydın et al. (20) recommended these values to be 1.9, 2.16, and 3.8, respectively. Getzler et al. (8) reported NLR $>2.5$ as an important marker of disease recurrence, particularly in NMIBC patients treated with BCG. Similarly to our study, the study by Favilla et al. (17) indicated NRL predicted disease recurrence but not progression; however, they used the NLR threshold of $\geq 3$.

Getzler et al. (8) reported that the efficacy of BCG was higher among patients with low NLR. Contrasting with the results of this study, our study indicates that NLR could be used to predict non-recurrence and non-progression at 1-year follow-up. In our study, NLR1, NLR2, and NLR3 measurements under BCG treatment showed significant differences, making NLR for an effective marker for prognosis and BCG response.

\section{Study Limitations}

This study has some limitations. The follow-up period was limited to 1 year, which may lead to selection bias owing to the retrospective design. We only included patients without progression and recurrence. This study aimed to establish the difference in NLR1 threshold according to EORTC progression and recurrence risk classification in patients with NMIBC after 1 year of BCG treatment who did not develop recurrence or progression. However, the NLR1 threshold may differ in patient groups without progression and recurrence at 3- and 5-year follow-ups. Furthermore, the magnitude of decrease in NLR values may predict non-recurrence and non-progression. Further well-designed prospective studies with longer followup periods ( 5 years) are required to validate these results.

\section{Conclusion}

The NLR value and the decrease in NLR at follow-up evaluations can be used as markers of prognosis in patients with NMIBC. NLR is an easily calculated, low-cost prognostic marker, and the thresholds could be determined basis the NMIBC risk classifications. Large prospective studies with longer followup periods are required to determine the normalized NLR thresholds.

\section{Ethics}

Ethics Committee Approval: This study complied with the Helsinki Declaration and was conducted with the approval of the local ethics committee (Hitit University Faculty of Medicine Ethics Committee; decision no: 87).

Informed Consent: Retrospective study.

Peer-review: Externally peer-reviewed.

Conflict of Interest: No conflict of interest was declared by the author. 
Financial Disclosure: The author declare that they have no relevant financial.

\section{References}

1. Babjuk M, Burger M, Compérat E, Gontero P, Mostafid AH, Palou J, van Rhijn BWG, Rouprêt M, Shariat SF, Sylvester R, Zigeuner R. Non-muscle-invasive Bladder Cancer. https://uroweb.org/guideline/non-muscle-invasivebladder-cancer/\#note_8 (available date 18/12/2019)

2. Global Burden of Disease Cancer Collaboration, Fitzmaurice $C$, Allen C, Barber RM, Barregard L, Bhutta ZA, Brenner H, Dicker DJ, ChimedOrchir O, Dandona R, Dandona L, Fleming T, Forouzanfar MH, Hancock J, Hay RJ, Hunter-Merrill R, Huynh C, Hosgood HD, Johnson CO, Jonas JB, Khubchandani J, Kumar GA, Kutz M, Lan Q, Larson HJ, Liang X, Lim SS, Lopez AD, MacIntyre MF, Marczak L, Marquez N, Mokdad AH, Pinho C, Pourmalek F, Salomon JA, Sanabria JR, Sandar LL, Sartorius B, Schwartz SM, Shackelford KA, Shibuya K, Stanaway J, Steiner C, Sun J, Takahashi K, Vollset SE, Vos T, Wagner JA, Wang H, Westerman R, Zeeb H, Zoeckler L, Abd-Allah $\mathrm{F}$, Ahmed MB, Alabed S, Alam NK, Aldhahri SF, Alem G, Alemayohu MA, Ali R, Al-Raddadi R, Amare A, Amoako Y, Artaman A, Asayesh H, Atnafu $N$, Awasthi A, Saleem HB, Barac A, Bedi N, Bensenor I, Berhane A, Bernabé E, Betsu B, Binagwaho A, Boneya D, Campos-Nonato I, Castañeda-Orjuela C, Catalá-López F, Chiang P, Chibueze C, Chitheer A, Choi AJ, Cowie B, Damtew S, das Neves J, Dey S, Dharmaratne S, Dhillon P, Ding E, Driscoll $T$, Ekwueme $D$, Endries AY, Farvid $M$, Farzadfar $F$, Fernandes J, Fischer J, G/Hiwot T, Gebru A, Gopalani S, Hailu A, Horino M, Horita N, Husseini A,

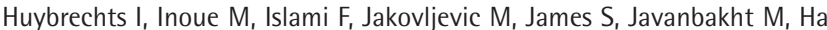
Jee $S$, Kasaeian A, Kedir MS, Khader YS, Khang YH, Kim D, Leigh J, Linn S, Lunevicius R, Abd El Razek HM, Malekzadeh R, Malta DC, Marcenes W, Markos D, Melaku YA, Meles KG, Mendoza W, Mengiste DT, Meretoja TJ, Miller TR, Mohammad KA, Mohammadi A, Mohammed S, Moradi-Lakeh M, Nagel G, Nand D, Le Nguyen $\mathrm{Q}$, Nolte $\mathrm{S}$, Ogbo FA, Oladimeji KE, Oren E, Pa M, Park EK, Pereira DM, Plass D, Qorbani M, Radfar A, Rafay A, Rahman M, Rana SM, Søreide K, Satpathy M, Sawhney M, Sepanlou SG, Shaikh MA, She J, Shiue I, Shore HR, Shrime G, So S, Soneji S, Stathopoulou V, Stroumpoulis K, Sufiyan MB, Sykes BL, Tabarés-Seisdedos R, Tadese F, Tedla BA, Tessema GA, Thakur JS, Tran BX, Ukwaja KN, Uzochukwu BSC, Vlassov W, Weiderpass E, Terefe MW, Yebyo HG, Yimam HH, Yonemoto N, Younis MZ, Yu C, Zaidi Z, El Sayed Zaki M, Zenebe ZZ, Murray CJL, Naghavi M. Global, regional, and national cancer incidence, mortality, years of life lost, years lived with disability, and disability-adjusted life-years for 32 cancer groups, 1990 to 2015: A Systematic Analysis for the Global Burden of Disease Study. JAMA Oncol 2017;3:524-548.

3. Ferlay J, Soerjomataram I, Dikshit R, Eser S, Mathers C, Rebelo M, Parkin DM, Forman D, Bray F. Cancer incidence and mortality worldwide: sources, methods and majör patterns in GLOBOCAN 2012. Int J Cancer 2015;136:E359-E386.

4. Siegel R, Ma J, Zou Z, Jemal A. Cancer statistics, 2014. CancerJ Clin 2014;64:9-29.

5. Antoni S, Ferlay J, Soerjomataram I, Znaor A, Jemal A, Bray F. Bladder Cancer Incidence and Mortality: A Global Overview and Recent Trends. Eur Urol 2017;71:96-108

6. Babjuk $M$, Burger $M$, Zigeuner $R$, Shariat SF, van Rhijn BW, Compérat $E$, Sylvester RJ, Kaasinen E, Böhle A, Palou Redorta J, Rouprêt M; European Association of Urology. EAU guidelines on non-muscle-invasive Urothelial carcinoma of the bladder: update 2013. Eur Urol 2013;64:639-653.

7. Burger $M$, Catto JW, Dalbagni G, Grossman HB, Herr H, Karakiewicz $P$, Kassouf W, Kiemeney LA, La Vecchia C, Shariat S, Lotan Y. Epidemiology and risk factors of urothelialbladder cancer. Eur Urol 2013;63:234-241.

8. Getzler I, Bahouth Z, Nativ 0, Rubinstein J, Halachmi S. Preoperative neutrophil to lymphocyte ratio improves recurrence prediction of nonmuscle invasive bladder cancer. BMC Urol 2018;18:90.
9. Hirahara T, Arigami T, Yanagita S, Matsushita D, Uchikado Y, Kita Y, Mori S, Sasaki K, Omoto I, Kurahara H, Maemura K, Okubo K, Uenosono Y, Ishigami $\mathrm{S}$, Natsugoe $\mathrm{S}$. Combined neutrophil-lymphocyte ratio and plateletlymphocyte ratio predicts chemotherapy response and prognosis in patients with advanced gastric cancer. BMC Cancer 2019;19:672.

10. Huang H, Wan X, Bai Y, Bian J, Xiong J, Xu Y, Sang X, Zhao H. Preoperative neutrophil-lymphocyte and platelet- lymphocyte ratios as independent predictors of T stages in hilar cholangiocarcinoma. Cancer Manag Res 2019;11:5157-5162.

11. Ceylan C, Doluoglu OG, Keleş I, Gazel E, Temucin T, Odabaş O, Karalar M. Importance of the neutrophil-to-lymphocyte ratio in muscle-invasive and non-muscle invasive bladder tumors. Urologia 2014;81:120-124.

12. Marchioni M, Primiceri $G$, Ingrosso M, Filograna $R$, Castellan $P$, De Francesco $P$, Schips L. The clinical use of the neutrophil to lymphocyte ratio (NLR) in urothelial cancer: a systematic review. Clin Genitourin Cancer 2016;14:473484.

13. Paramanathan A, Saxena A, Morris DL. A systematic review and metaanalysis on the impact of preoperative neutrophil lymphocyte ratio on long term outcomes after curative intent resection of solid tumours. Surg Oncol 2014;23:31-39.

14. Mano R, Baniel J, Shoshany O, Margel D, Bar-On T, Nativ O, Rubinstein J, Halachmi S. Neutrophil-to-lymphocyte ratio predicts progression and recurrence of non-muscle-invasive bladder cancer. Urol Oncol 2015;33:67. e1-7

15. Racioppi M, Di Gianfrancesco L, Ragonese M, Palermo G, Sacco E, Bassi PF. Can Neutrophil-to-Lymphocyte ratio predict the response to BCG in highrisk non muscle invasive bladder cancer? Int Braz J Urol 2019;45:315-324.

16. Yuk HD, Jeong CW, Kwak C, Kim HH, Ku JH. Elevated neutrophil to lymphocyte ratio predicts poor prognosis in non-muscle Invasive bladder cancer patients: Initial Intravesical Bacillus Calmette-Guerin treatment after transurethral resection of bladder tumor setting. Front Oncol 2019;17;8:642.

17. Favilla V, Castelli T, Urzi D, Reale G, Privitera $S$, Salici A, Russo Gl, Cimino $\mathrm{S}$, Morgia G. Neutrophil to lymphocyte ratio, a biomarker in non-muscle invasive bladder cancer: a single-institutional longitudinal study. Int Braz J Urol 2016;42:685-693.

18. D'Andrea D, Moschini M, Gust $K$, Abufaraj M, Ozsoy M, Mathieu R, Soria $F$, Briganti A, Rouprêt M, Karakiewicz Pl, Shariat SF. Prognostic role of neutrophil-to- lymphocyte ratio in primary non-muscle-invasive bladder cancer. Clin Genitourin Cancer 2017;15:e755-e764.

19. Çelen S, Günseren KÖ, Özlülerden Y, Mete A, Tuncay ÖL, Yavaşcaoğlu İ. Does neutrophil-lymphocyte ratio show recurrence in patients who underwent curative resection for non-muscle-invasive bladder cancer? J Surg Med 2019;3:324-327.

20. Aydın M, Bitkin A, Kadıhasanoğlu M, İrkılata L, Akgüneş E, Keleş $M$, Atilla MK. Correlation of neutrophil-lymphocyte ratio and risk scores in nonmuscle invasive bladder cancer. Actas Urol Esp 2019;43:503-508.

21. Kaynar M, Goktas S. Neutrophil-to-lymphocyte ratio predicts progression and recurrence of non-muscle-invasive bladder cancer. Urol Oncol 2015;33:497.

22. Cimen HI, Halis F, Saglam HS, Gokce A. Can neutrophil to lymphocyte ratio predict lamina propria invasion in patients with non-muscle invasive bladder cancer? Int Braz J Urol 2017;43:67-72. 